\title{
BONE MINERAL DENSITY IN RELATION TO METABOLIC SYNDROME COMPONENTS IN POSTMENOPAUSAL WOMEN WITH DIABETES MELLITUS TYPE 2
}

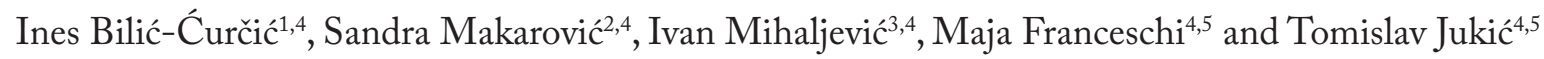 \\ ${ }^{1}$ Clinical Department of Endocrinology and Metabolism Disorders, \\ ${ }^{2}$ Clinical Department of Cardiovascular Diseases and Intensive Care, \\ ${ }^{3}$ Clinical Department of Nuclear Medicine and Radiation Protection, Osijek University Hospital Center; \\ ${ }^{4}$ School of Medicine, Josip Juraj Strossmayer University, Osijek; ${ }^{5}$ Clinical Department of Oncology \\ and Nuclear Medicine, Sestre milosrdnice University Hospital Center and School of Medicine, Zagreb, Croatia
}

SUMMARY - Diabetes mellitus type 2 is associated with greater bone mineral density (BMD) due to obesity, although rapid bone loss observed over time could be explained by elevated chronic inflammation. The objective of this study was to investigate the relationship between central adiposity and hyperinsulinemia, as well as inflammation markers with vertebral and femoral BMD and bone turnover markers in postmenopausal women with type 2 diabetes. Femoral and vertebral BMD, osteocalcin, pyrilinks $\mathrm{D}$, beta-CrossLaps (B-CTx), insulin, C-reactive protein (CRP), fibrinogen and plasminogen activator inhibitor-1 (PAI-1) were measured in 114 postmenopausal female patients with diabetes type 2 . The patients of similar age, $\mathrm{HbA} 1 \mathrm{c}$ levels and diabetes duration were divided into 2 groups based on their body mass index (BMI) values: lower or equal to $27 \mathrm{~kg} / \mathrm{m}^{2}$ (31 patients) and higher than $27 \mathrm{~kg} / \mathrm{m}^{2}$ (83 patients). Lower levels of osteocalcin ( $\left.\mathrm{p}=0.001\right), \mathrm{B}-\mathrm{CTx}(\mathrm{p}=0.000007)$ and pyrilinks D ( $\mathrm{p}=0.0365)$, and higher femoral BMD ( $\mathrm{p}=0.00006)$, insulin level ( $\mathrm{p}=0.0002)$, PAI-1 $(p=0.00000)$ and CRP $(p=0.002)$ were found in the overweight group. There were no significant differences in vertebral BMD and fibrinogen. Osteocalcin and B-CTx showed inverse correlation, and femoral BMD positive correlation with waist circumference, insulin level and PAI-1. This suggests that abdominal obesity and hyperinsulinemia as components of the metabolic syndrome could increase femoral BMD by lowering bone rate. In addition, the only inflammation marker linked with femoral BMD was PAI-1, which is associated with increased mineralization of cortical bone in mouse models.

Key words: Diabetes mellitus, type 2; Adiposity; Hyperinsulinism; Inflammation; Bone density; Menopause

\section{Introduction}

Diabetes mellitus type 2 (T2DM) can influence bone through several mechanisms, some of which may

Correspondence to: Ines Bilić-Ćurčic, $M D$, Clinical Department of Endocrinology and Metabolism Disorders, Osijek University Hospital Center, J. Huttlera 4, HR-31000 Osijek, Croatia

E-mail: ibcurcic@mefos.hr

Received January 25, 2016, accepted December 30, 2016 have contradictory effects. Obesity or high body mass index (BMI) has a protective effect against excessive bone loss with aging ${ }^{1-4}$. This is probably a result of enhanced osteoblast differentiation due to heavier mechanical loading of bone, whereas hyperinsulinemia may promote bone formation ${ }^{5}$. Higher glucose levels in the blood interact with several proteins generating higher concentration of advanced glycation end-products (AGEs) in collagen that may reduce 
bone strength ${ }^{6}$. Accumulated AGEs in the body may stimulate apoptosis of osteoblasts, thereby contributing to deficient bone formation ${ }^{7}$.

The metabolic syndrome includes obesity, dyslipidemia, impaired glucose tolerance, and hypertension ${ }^{8}$, and is also associated with low-grade inflammation, as well as diabetes mellitus type $2(\mathrm{~T} 2 \mathrm{DM})^{9}$. In osteoporosis, bone mineral density (BMD) is reduced and bone microarchitecture deteriorated, which leads to an increased risk of fracture ${ }^{10}$. Proinflammatory cytokines up-regulate receptor activator of nuclear factor- $\mathrm{KB}$ ligand, leading to increased bone resorption ${ }^{11-13}$. Some authors have suggested that elevated $\mathrm{C}$-reactive protein (CRP) is associated with osteoporosis and nontraumatic fracture ${ }^{14,15}$.

Many studies investigated the relationship between T2DM and bone metabolism, but their results were inconsistent. For patients with T2DM, some authors have reported increased $\mathrm{BMD}$, others have reported decreased BMD, and some have reported unaltered $\mathrm{BMD}^{16}$.

The aim of this study was to investigate the relationship between components of the metabolic syndrome, central adiposity and hyperinsulinemia, as well as inflammation markers with vertebral and femoral $\mathrm{BMD}$ and bone turnover markers in postmenopausal women with T2DM.

\section{Materials and Methods}

\section{Subjects}

This study complied with the Declaration of Helsinki and was approved by the Ethics Committee of the Osijek University Hospital Center. The subjects enrolled in the study were a subset of all patients having visited or being hospitalized for regular medical check-up at the Department of Endocrinology and Diabetes, Osijek University Hospital Center. This cross-sectional study included 114 female postmenopausal patients with T2DM aged $\geq 45$ years, with similar $\mathrm{HbA1c}$ levels and diabetes duration, divided into 2 groups based on their BMI values: lower or equal to 27 $\mathrm{kg} / \mathrm{m}^{2}$ (31 patients) and higher than $27 \mathrm{~kg} / \mathrm{m}^{2}(83 \mathrm{pa}-$ tients) ${ }^{17}$. Patients with a history of the following conditions were excluded from the study: those taking medication for osteoporosis; those receiving hormone replacement therapy or other medications such as glu- cocorticoids, affecting BMD; those with conditions such as malignancy, thyroid disease or thyroid functional abnormality that would be apparent causes for abnormal bone mass; and those with acute infectious disease or chronic inflammatory diseases. BMI was calculated from body weight and height $\left(\mathrm{kg} / \mathrm{m}^{2}\right)$. Waist circumference at the bending point was measured in centimeters with the participant wearing only a single layer of clothes. Postmenopausal status was defined, through close history taking, as cessation of menstruation for at least 1 year.

\section{BMD measurement}

Bone mineral density of lumbar spine and total femur was measured by dual energy $\mathrm{x}$-ray absorptiometry (Dexa QDR 1000, Hologic, Inc., Waltham, MA, USA) calibrated daily using a standard phantom provided by the manufacturer. Lumbar spine BMD was the mean of lumbar vertebrae 1-4.

\section{Biochemical assay}

At study entry, all women underwent blood analyses to verify their healthy state. Bone metabolism was evaluated by determining serum levels of osteocalcin (OC) as a marker of bone formation, and urinary pyrilinks-D (PYD) and beta-CrossLaps (B-CTx) as markers of bone resorption ${ }^{18}$. Second morning urine sample was collected and PYD in urine was measured using competitive enzyme immunoanalysis by commercially available kit, according to the manufacturer's protocol (Metra Biosystem Inc., Mountain View, USA; reference value 3.0-7.4 nM DPD/mM creatinine). Serum OC levels were assayed by an immunoradiometric assay (IRMA) with commercially available kits, according to the manufacturer's recommendations (BioSource Europe S.A., Nivelles, Belgium; reference value 5-25 ng/mL). Serum Beta-CTx was measured by electrochemiluminescent immunoassay (ECLIA) by commercially available kit, according to the manufacturer's protocol (Roche-B-Crosslaps assay, Roche Diagnostics, Mannheim, Germany). Serum insulin levels were determined with RIA method. Automated CRP measurement was performed by immunoturbidimetry on a modular clinical analyzer (Olympus, Beckman Coulter, Inc., USA). Fibrinogen and plasminogen activator inhibitor-1 (PAI-1) were determined by coagulometry 
using a BCS automated photometric coagulation analyzer (Behring Coagulation System, Marburg, Germany).

Table 1. Baseline characteristics of subjects relative to body mass index $\left(B M I, \mathrm{~kg} / \mathrm{m}^{2}\right)$

\begin{tabular}{|l|c|c|c|c|c|}
\hline \multirow{2}{*}{ Variable } & \multicolumn{2}{|c|}{$\begin{array}{c}\text { BMI } \leq 27 \\
(\mathrm{n}=31)\end{array}$} & \multicolumn{2}{c|}{$\begin{array}{c}\text { BMI }>27 \\
(\mathrm{n}=83)\end{array}$} & \multirow{2}{*}{$\mathrm{p}<0.05$} \\
\cline { 2 - 6 } & Mean & SD & Mean & SD & \\
\hline Waist & 88.32 & 8.71 & 99.90 & 9.79 & 0.0000 \\
circumference & 7.61 & 3.45 & 13.36 & 12.78 & 0.0002 \\
Insulin & 2.46 & 1.25 & 4.47 & 2.03 & 0.0000 \\
PAI-1 & 2.86 & 2.99 & 5.54 & 5.87 & 0.0025 \\
CRP & 4.06 & 0.79 & 4.14 & 0.86 & 0.9356 \\
Fibrinogen & 7.59 & 3.03 & 6.31 & 2.54 & 0.0365 \\
Pyrilinks D & 9.61 & 4.53 & 6.77 & 3.40 & 0.0012 \\
Osteocalcin & 0.60 & 0.32 & 0.34 & 0.18 & 0.0003 \\
B-CTx & 0.78 & 0.13 & 0.91 & 0.13 & 0.0000 \\
Femoral BMD & 0.86 & 0.17 & 0.92 & 0.10 & 0.0750 \\
Vertebral BMD & 12.98 & 7.31 & 10.42 & 6.66 & 0.5087 \\
Diabetes & 10.11 & 2.23 & 9.63 & 2.17 & 0.8310 \\
duration & HbA1c & & &
\end{tabular}

PAI-1 = plasminogen activator inhibitor -1 CRP $=\mathrm{C}$-reactive protein; $\mathrm{B}-\mathrm{CTx}=$ beta-CrossLaps; $\mathrm{BMD}=$ bone mineral density; $\mathrm{HbA} 1 \mathrm{c}=$ glycated hemoglobin

\section{Statistical analysis}

Results were processed using descriptive statistical analysis. Continuous variables were summarized using sample size, mean, median, standard deviation, and minimum and maximum values. Significance was declared at a two-sided 0.05 level, unless otherwise specified. Mann Whitney as a non-parametric test was used to calculate distribution differences for continuous variables. Spearman's correlation coefficients were computed to estimate the magnitude of the association between the variables of interest. Statistical analysis was performed using StatSoft, Statistica 8.0.

\section{Results}

Baseline characteristics of the subjects are summarized in Table 1. Both groups had similar diabetes duration and $\mathrm{HbA1c}$ levels. There was no significant difference in vertebral BMD or fibrinogen between the two groups. The mean values of PAI- $1(\mathrm{p}=0.000000)$, CRP ( $\mathrm{p}=0.002)$ and insulin ( $\mathrm{p}=0.0002)$, as well as total femoral BMD ( $\mathrm{p}=0.00006)$ were significantly higher, whereas bone turnover markers, i.e. osteocalcin ( $\mathrm{p}=$ $0.001)$, B-CTx $(\mathrm{p}=0.000007)$ and pyrilinks $\mathrm{D}(\mathrm{p}=$ 0.0365 ) were significantly lower in the overweight group. This could suggest that bone activity was sup-

Table 2. Correlation of bone mineral density and bone turnover markers with inflammatory markers and components of metabolic syndrome

\begin{tabular}{|c|c|c|c|c|c|}
\hline & & Femoral BMD & Vertebral BMD & Osteocalcin & B-CTx \\
\hline \multirow[t]{2}{*}{ Waist circumference } & $\begin{array}{l}\text { Correlation } \\
\text { coefficient }\end{array}$ & 0.3616 & 0.2385 & -0.2693 & -0.3359 \\
\hline & p-value & 0.001 & 0.027 & 0.011 & 0.002 \\
\hline \multirow[t]{2}{*}{ Insulin } & $\begin{array}{l}\text { Correlation } \\
\text { coefficient }\end{array}$ & 0.02981 & 0.0126 & -0.2439 & -0.2239 \\
\hline & $\mathrm{p}$-value & 0.005 & 0.908 & 0.021 & 0.037 \\
\hline \multirow[t]{2}{*}{ PAI-1 } & $\begin{array}{l}\text { Correlation } \\
\text { coefficient }\end{array}$ & 0.345 & 0.1487 & -0.2809 & -0.2653 \\
\hline & $\mathrm{p}$-value & 0.001 & 0.172 & 0.007 & 0.012 \\
\hline \multirow[t]{2}{*}{$\mathrm{CRP}$} & $\begin{array}{l}\text { Correlation } \\
\text { coefficient }\end{array}$ & 0.2928 & 0.0952 & -0.0185 & -0.1088 \\
\hline & $\mathrm{p}$-value & 0.116 & 0.395 & 0.096 & 0.331 \\
\hline \multirow[t]{2}{*}{ Fibrinogen } & $\begin{array}{l}\text { Correlation } \\
\text { coefficient }\end{array}$ & 0.318 & 0.331 & 0.0230 & 0.0313 \\
\hline & $\mathrm{p}$-value & 0.774 & 0.765 & 0.831 & 0.775 \\
\hline
\end{tabular}

$\mathrm{BMD}=$ bone mineral density; $\mathrm{B}-\mathrm{CTx}=$ beta-CrossLaps; $\mathrm{PAI}-1$ = plasminogen activator inhibitor-1; $\mathrm{CRP}=\mathrm{C}$-reactive protein 
pressed as a result of hyperinsulinemia present in $\mathrm{pa}^{-}$ tients with visceral obesity, thus blocking bone resorption leading to higher femoral BMD.

Spearman's correlation yielded a strongly significant negative association of B-CTx and OC with waist circumference, insulin levels and PAI-1 (Table 2), also indicating supression of bone turnover rate due to hyperinsulinemia. Furthermore, there was no corellation between inflammation markers (CRP and fibrinogen) and bone turnover markers. Total femoral BMD was significantly positively associated with waist circumference, insulin levels and PAI-1, while vertebral BMD correlated significantly only with waist circumference (Table 2). There was no correlation with $\mathrm{CRP}$ or fibrinogen.

\section{Discussion}

Although it is generally accepted that obesity has a protective effect on bone tissue, some studies have revealed the opposite, i.e. that obesity is not beneficial or has a negative effect on osteoporosis. In a study of postmenopausal Korean women ${ }^{19}$, waist circumference, which provides an indication of central obesity (visceral fat mass), was related to low BMD and osteoporotic vertebral fractures. In contrast, our research demonstrated significant positive correlation between vertebral and femoral BMD and waist circumference, which could be explained by higher circulating insulin levels in central obesity. Consequently, hyperinsulinemia significantly correlated with higher femoral BMD, but was negatively associated with bone turnover markers, suggesting inhibition of bone resorption due to suppression of bone activity.

Diabetes mellitus type 2 is a condition that includes obesity, a factor associated with enhanced $\mathrm{BMD}$, and inflammation, a factor thought to reduce BMD, which could be present in all types of diabetes $^{20,21}$. However, low grade inflammation is more severe in subjects with high insulin resistance than in those with low insulin resistance ${ }^{22,23}$, presumably leading to reduced BMD in T2DM. Some studies have suggested that chronic inflammation has a deleterious effect on BMD, resulting in development of osteoporosis $^{14,24}$. Therefore, T2DM has a potential dual effect on bone health, i.e. protective effect due to obesity and adverse one as a result of bone resorption activated by chronic inflammation.
Whereas previous work suggests that osteoporosis is linked to inflammation, it is not yet clear whether higher CRP levels are associated with bone loss ${ }^{15}$. In a recently published study, CRP was associated inversely with composite strength index, but was not associated with femoral neck or lumbar spine $\mathrm{BMD}^{25}$, which is consistent with our observation. The only inflammation marker linked with higher femoral BMD was PAI-1, a recognized modulator of matrix implicated in the regulation of bone homeostasis. Over-expression of PAI-1 in transgenic mice resulted in increased mineralization and biomechanical properties of mouse femora ${ }^{26}$. In a study performed on PAI-1 knockout mice, PAI-1 (and potentially the plasminogen extracellular matrix protease system) was demonstrated to be an important regulator of bone size during developmental growth, playing a regulatory role in the determination of fracture callus size, cartilage formation, and resorption during bone fracture repair ${ }^{27}$. PAI-1 also negatively correlated with bone turnover markers, once again suggesting higher mineral density as a result of inhibited bone resorption. In a recently published study increased PAI levels were associated with higher BMD in obese diabetic female patients implicating direct involvement in bone metabolism ${ }^{28}$.

Total femoral BMD was significantly higher in the overweight group, whereas no significant difference in the vertebral BMD was noted, implying that the effects of obesity and hyperinsulinemia on BMD varied by anatomic site, as shown in previous studies ${ }^{29}$.

Our study had some limitations. Since our data were cross-sectional, we had a limited ability to assess temporal relationship between the components of metabolic syndrome and BMD. Further longitudinal studies are needed to elucidate the association between bone and energy metabolism.

These findings suggest that the protective effect of the metabolic syndrome components, i.e. abdominal obesity and hyperinsulinemia in T2DM could prevail over deleterious effect of chronic inflammation on bone metabolism, thus resulting in increased total femoral BMD.

\section{References}

1. Felson DT, Zhang Y, Hannan MT, Anderson JJ. Effects of weight and body mass index on bone mineral density in men and women: the Framingham study. J Bone Miner Res. 1993; 8(5):567-73. DOI:10.1056/NEJM199310143291601 
2. Marcus R, Greendale G, Blunt BA, Bush TL, Sherman S, Sherwin $\mathrm{R}$, et al. Correlates of bone mineral density in the postmenopausal estrogen/progestin interventions trial. J Bone Miner Res. 1994;9:1467-76. DOI:10.1002/jbmr.5650090920

3. Ravn P, Cizza G, Bjarnason NH, Thompson D, Daley M, Wasnich $\mathrm{RD}$, et al. Low body mass index is an important risk factor for low bone mass and increased bone loss in early postmenopausal women. Early Postmenopausal Intervention Cohort (EPIC) study group. J Bone Miner Res. 1999;14(9):1622-7. DOI:10.1359/jbmr.1999.14.9.1622

4. De Laet C, Kanis JA, Oden A, Johanson H, Johnell O, Delmas $\mathrm{P}$, et al. Body mass index as a predictor of fracture risk: a metaanalysis. Osteoporos Int. 2005;16(11):1330-8. DOI:10.1007/ s00198-005-1863-y

5. Reid I, Evans M, Cooper G, Ames RW, Stapleton J. Circulating insulin levels are related to bone density in normal postmenopausal women. Am J Physiol Endocrinol Metab. 1993; 265(4 Pt 1):E655-9.

6. Paul R, Bailey A. Glycation of collagen: the basis of its central role in the late complications of ageing and diabetes. Int J Biochem Cell Biol. 1996;28(12):1297-310.

7. Alikhani M, Alikhani Z, Boyd C, McClellan CM, Raptis M, Liu R, et al. Advanced glycation end products stimulate osteoblast apoptosis via the MAP kinase and cytosolic apoptotic pathways. Bone. 2007;40(2):345-53. DOI:10.1016/j.bone. 2006.09.011

8. Tucak-Zorić S, Curčić IB, Mihalj H, Dumančić I, Zelić Z, Cetina NM, et al. Prevalence of metabolic syndrome in the interior of Croatia: the Baranja region. Coll Antropol. 2008; 32(3):659-65.

9. Lontchi-Yimagou E, Sobngwi E, Matsha TE, Kengne AP. Diabetes mellitus and inflammation. Curr Diab Rep. 2013; 13(3):435-44. DOI:10.1007/s11892-013-0375-y

10. Bilić-Ćurčić I, Milas-Ahić J, Smolić M, Smolić R, Mihaljević I, Tucak-Zorić S. Urolithiasis and osteoporosis: clinical relevance and therapeutic implications. Coll Antropol. 2009; Suppl 2:189-92.

11. Jones DH, Kong Y-Y, Penninger JM. Role of RANKL and RANK in bone loss and arthritis. Ann Rheum Dis. 2002;61 Suppl 2:ii32-9.

12. Hofbauer LC, Schoppet M. Clinical implications of the osteoprotegerin/RANKL/RANK system for bone and vascular diseases. JAMA. 2004;292(4):490-5. DOI:10.1001/jama.292. 4.490

13. Smith BJ, Lerner MR, Bu SY, Lucas EA, Hanas JS, Lightfoot $\mathrm{SA}$, et al. Systemic bone loss and induction of coronary vessel disease in a rat model of chronic inflammation. Bone. 2006; 38(3):378-86. DOI:10.1016/j.bone.2005.09.008

14. Ganesan K, Teklehaimanot S, Tran TH, Asuncion M, Norris $\mathrm{K}$. Relationship of $\mathrm{C}$-reactive protein and bone mineral density in community-dwelling elderly females. J Natl Med Assoc. 2005;97(3):329-33.
15. Schett G, Kiechl S, Weger S, Pederiva A, Mayr A, Petrangeli $\mathrm{M}$, et al. High-sensitivity $\mathrm{C}$-reactive protein and risk of nontraumatic fractures in the Bruneck study. Arch Intern Med. 2006;166(22):2495-501. DOI:10.1001/archinte.166.22.2495

16. Abdulameer SA, Sulaiman SA, Hassali MA, Subramaniam K, Sahib MN. Osteoporosis and type 2 diabetes mellitus: what do we know, and what we can do? Patient Prefer Adherence. 2012;6:435-48. DOI:10.2147/PPA.S32745

17. Kuczmarski RJ, Flegal KM, Campbell SM, Johnson CJ. Increasing prevalence of overweight among US adults. The $\mathrm{Na}$ tional Health and Nutrition Examination Surveys, 1960 to 1991.JAMA. 1994;272(3):205-11.

18. Mihaljević I, Mudri D, Smolić R, Smolić M, Tucak-Zorić S. Biochemical bone turnover markers: significance in patients with osteoporosis. Coll Antropol. 2009;33 Suppl 2:21-4.

19. Kim KC, Shin DH, Lee SY, Im JA, Lee DC. Relation between obesity and bone mineral density and vertebral fractures in Korean postmenopausal women. Yonsei Med. 2010;51(6):857-63. DOI:10.3349/ymj.2010.51.6.857

20. Aktulay A, Engin-Ustun Y, Ozkan MS, Erkaya S, Kara M, Kaymak O, et al. Gestational diabetes mellitus seems to be associated with inflammation. Acta Clin Croat. 2015;54(4): 475-8.

21. Bulum T, Duvnjak L. Insulin resistance in patients with type 1 diabetes: relationship with metabolic and inflammatory parameters. Acta Clin Croat. 2013;52(1):43-51.

22. Mclaughlin T, Abbasi F, Lamendola C, Liang L, Reaven G, Schaaf $\mathrm{P}$, et al. Differentiation between obesity and insulin resistance in the association with C-reactive protein. Circulation. 2002;106(23):2908-12.

23. Rhee EJ, Kim YC, Lee WY, Jung CH, Sung KC, Ryu SH, et al. Comparison of insulin resistance and serum high-sensitivity C-reactive protein levels according to the fasting blood glucose subgroups divided by the newly recommended criteria for fasting hyperglycemia in 10059 healthy Koreans. Metabolism. 2006;55(2):183-7. DOI:10.1016/j.metabol.2005.08.010

24. Koh JM, Khang YH, Jung CH, Bae S, Kim DJ, Chung YE, et al. Higher circulating hsCRP levels are associated with lower bone mineral density in healthy pre- and postmenopausal women: evidence for a link between systemic inflammation and osteoporosis. Osteoporos Int. 2005;16(10):1263-71. DOI: 10.1007/s00198-005-1840-5

25. Ishii S, Cauley JA, Greendale GA, Crandall CJ, Danielson ME, Ouchi Y, Karlamangla AS. C-reactive protein, bone strength, and nine-year fracture risk: data from the Study of Women's Health Across the Nation (SWAN). J Bone Miner Res. 2013; 28(7):1688-98. DOI:10.1002/jbmr.1915

26. Nordstrom SM, Carleton SM, Carson WL, Eren M, Phillips CL, Vaughan DE. Transgenic over-expression of plasminogen activator inhibitor-1 results in age-dependent and gender-specific increases in bone strength and mineralization. Bone. 2007; 41(6):995-1004. DOI:10.1016/j.bone.2007.08.020 
27. Rundle CH, Wang X, Wergedal JE, Mohan S, Lau KH. Fracture healing in mice deficient in plasminogen activator inhibitor-1. Calcif Tissue Int. 2008;83(4):276-84. DOI: 10.1007/ s00223-008-9169-7

28. Canecki-Varžić S, Prpić-Križevac I, Bilić-Ćurčić I. Plasminogen activator inhibitor-1 concentrations and bone mineral density in postmenopausal women with type 2 diabetes mellitus.
BMC Endocr Disord. 2016 Mar 3;16:14. DOI: 10.1186/ s12902-016-0094-x.

29. Yamaguchi T, Kanazawa I, Yamamoto M, Kurioka S, Yamauchi M, Yano S, et al. Associations between components of the metabolic syndrome versus bone mineral density and vertebral fractures in patients with type 2 diabetes. Bone. 2009;45(2):174-9. DOI: $10.1016 /$ j.bone.2009.05.003

Sažetak

\section{POVEZANOST KOŠTANE MINERALNE GUSTOĆE I SASTAVNICA METABOLIČKOG SINDROMA U POSTMENOPAUZALNIH ŽENA SA ŠEĆERNOM BOLEŠĆU TIPA 2}

\section{Bilic-Cururčic, S. Makarović, I. Mihaljević, M. Franceschi i T. Jukić}

Šećerna bolest tipa 2 povezana je s većom koštanom mineralnom gustoćom (bone mineral density, BMD) zbog debljine, iako se zamijećeni ubrzani gubitak koštane mase tijekom vremena može objasniti prisustvom kronične upale. Cilj ovoga istraživanja bio je utvrditi povezanost biljega koštane pregradnje i koštane gustoće s centralnom debljinom, hiperinzulinemijom kao i upalnim biljezima u postmenopauzalnih žena sa šećernom bolešću tipa 2. U 114 ispitanica izmjerena je koštana gustoća kralježnice i kuka, određeni su osteokalcin, pirilinks D, beta-CrossLaps (B-CTx), inzulin, C-reaktivni protein (CRP), fibrinogen $\mathrm{i}$ inhibitor aktivatora plazminogena-1 (PAI-1). Ispitanice slične dobi, podjednakog trajanja dijabetesa te HbA1c bile su podijeljene u dvije skupine prema indeksu tjelesne mase (ITM): niži ili jednaki $27 \mathrm{~kg} / \mathrm{m}^{2}$ (31 ispitanica) te veći od 27 $\mathrm{kg} / \mathrm{m}^{2}$ (83 ispitanice). Niže vrijednosti osteokalcina ( $\left.\mathrm{p}=0,001\right)$, B-CTx $(\mathrm{p}=0,000007)$ i pirilinksa $\mathrm{D}(\mathrm{p}=0,0365)$ te više vrijednosti košane gustoće kuka ( $\mathrm{p}=0,00006)$, inzulina ( $\mathrm{p}=0,0002)$, PAI-1 ( $\mathrm{p}=0,0000)$ i CRP $(\mathrm{p}=0,002)$ utvrđene su u skupini s prekomjernom tjelesnom težinom. Nije bilo statistički značajne razlike u koštanoj gustoći kralježnice i vrijednosti fibrinogena. Osteokalcin i B-CTx su negativno korelirali, dok je BMD kuka bio u pozitivnoj korealciji s opsegom struka, inzulinom i PAI-1. Ovi rezultati upućuju na to da sastavnice metaboličkog sindroma, centralna debljina i hiperinzulinemija utječu na povećanje koštane gustoće kuka inhibirajući koštanu pregradnju. Jedini upalni biljeg povezan s BMD kuka bio je PAI-1 koji povećava mineralizaciju kortikalne kosti na mišjem modelu.

Ključne riječi: Dijabetes melitus tip 2; Pretilost; Hiperinzulinemija; Upala; Kost, gustoća; Menopauza 